JURNAL ABDI INSANI UNIVERSITAS MATARAM

Volume 8, Nomor 3, Desember 2021

Homepage : http://abdiinsani.unram.ac.id. e-ISSN : 2657-0629

\title{
EDUKASI MENGENAI NYERI PUNGGUNG BAWAH (NPB) PADA PASIEN POLI SARAF RUMAH SAKIT UNIVERSITAS MATARAM
}

\section{Low Back Pain Education to the Neurologi Polyclinic patient of Unram Hospital}

\author{
Muhammad Ghalvan Sahidu, Ilsa Hunaifi, Herpan Syafii Harahap
}

Departemen Neurologi, Fakultas Kedokteran Universitas Mataram, NTB, Indonesia

\section{Jl. Pendidikan Nomor 37 Kota Mataram, NTB}

Alamat korespondensi : allansah87@gmail.com

(Tanggal Submission: 1 6November 2021, Tanggal Accepted : 17 Desember 2021)

\section{Kata Kunci : \\ nyeri punggung bawah, NPB, saraf}

Abstrak :

Keluhan nyeri punggung bawah (NPB) sering dijumpai pada praktik sehari-hari. Sebanyak $17-31 \%$ dari total populasi pernah mengalami NPB semasa hidupnya. Hal tersebut menyebabkan penurunan kualitas hidup serta memiliki dampak sosial dan ekonomi yang buruk. Kegiatan pengabdian kepada masyarakat ini bertujuan untuk mengedukasi masyarakat awam mengenai nyeri punggung bawah dan bagaimana pencegahannya. Pengabdian ini dilaksanakan di poli saraf Rumah Sakit Universitas Mataram. Sebanyak 13 pasien saraf yang berada di depan poli mengikuti kegiatan, yang meliputi pre-test, penyuluhan dalam bentuk slide mengenai nyeri punggung bawah (NPB), dan diakhiri dengan post-test. Soal-soal pre-test dan post-test yang diberikan adalah 10 butir soal jenis pilihan ganda seputar penyakit nyeri punggung bawah (NPB), dan diambil nilai rerata nya. Dalam kegiatan ini, dapat dipaparkan perbedaan rerata nilai pre-test dan post-test pada pasien, antara lain rerata 76.9 untuk pre-test dan 82.2 untuk post-test. Sebanyak 9 pasien $(60 \%)$ mengalami peningkatan nilai atau pengetahuan, dan 3 pasien (23\%) tidak menunjukkan adanya peningkatan, 1 pasien yang pre-test dan post-test nya mendapat nilai sempurna (100), dan nilai post-test yang lebih rendah dari nilai pre-test sebanyak 1 pasien (7\%). Dalam kegiatan pengabdian ini menunjukkan bahwa komunikasi, informasi, dan edukasi merupakan solusi yang efektif untuk meningkatan pengetahuan pasien. Pengabdian ini merupakan langkah awal untuk kegiatan intervensi promosi yang perlu ditindaklanjuti dengan kegiatan serupa pada populasi yang lebih luas, sehingga upaya penemuan penyakit NPB menjadi meningkat dan luaran klinis penderitanya menjadi lebih baik.

Panduan sitasi / Citation guidance (APPA $7^{\text {th }}$ edition) :

Sahidu, M.G., Hunaifi, I., \& Harahap, H.S. (2021). Edukasi Mengenai Nyeri Punggung Bawah (Npb) Pada Pasien Poli Saraf Rumah Sakit Universitas Mataram. Abdi Insani, 8 (3), 319-323. http://doi.org/10.29303/abdiinsani.v8i3.432 


\section{PENDAHULUAN}

Nyeri punggung bawah (NPB) merupakan nyeri, ketegangan otot, atau kekakuan yang terlokalisir di antara batas iga bagian bawah dan lipatan gluteus inferior, dengan atau tanpa penjalaran ke paha dan/atau tungkai (scatiaca). NPB dapat terjadi dengan atau tanpa nyeri radikular atau nyeri alih yang menandakan kerusakan jaringan organ lain. Pada prinsipnya, NPB disebabkan oleh kerusakan jaringan saraf dan nonsaraf yang sangat dipengaruhi oleh aspek psikologis.

Keluhan NPB sering dijumpai pada praktik sehari-hari. Sebanyak $17-31 \%$ dari total populasi pernah mengalami NPB semasa hidupnya. Oleh karena NPB sangat dipengaruhi oleh aktivitas fisik dan posisi tubuh, maka pasien NPB memiliki keterbatasan dalam bergerak (disabilitas). Hal tersebut menyebabkan penurunan kualitas hidup serta memiliki dampak sosial dan ekonomi yang buruk.

Berdasarkan studi The Global Burden of Disease tahun 2010, NPB merupakan penymbang terbesar kecacatan global, yang diukur melalui years lived with disability (YLD). Studi di inggris mengemukakan bahwa NPB merupakan penyebab utama disabilitas dewasa muda yang menimbulkan lebih dari 100 juta hari kerja hilang tiap tahun. Dengan demikian, NPB penyebab penurunan produktivitas kerja dan berkaitan dengan beban ekonomi yang besar (Aninditha \& Wiratman, 2017).

Secara temporal, NPB terbagi menjadi akut (<6 minggu), subakut (7-12 minggu), kronik ( $>12$ minggu/3 bulan), dan rekuren (berulang). Sebagian besar penderita NPB mengalami rekurensi, yang sebenarnya merupakan bentuk eksaserbasi akut pada NPB kronik. Penanganan NPB akut yang tidak cepat dan adekuat akan berakibat progresivitas keluhan menjadi kronik dan rekuren. Selain itu, faktor stress psikologis juga turut meningkatkan risiko kronisitas NPB. Kondisi kronik seperti ini harus dicegah oleh klinisi yang menangani NPB.

Prevalensi NPB cukup bervariasi, dengan hasil studi di negara-negara berkembang menunjukkan prevalensi pertahun sekitar 22-65\%. Data kelompok Studi Nyeri PERDOSSI menyatakan sebesar $18,37 \%$ dari keseluruhan pasien nyeri adalah NPB. Data epidemiologi lain memperkirakan sekitar 40\% penduduk Jawa Tengah berusia antara 65 tahun pernah menderita nyeri punggung, dengan prevalensi $18,2 \%$ pada laki-laki dan 13,6\% pada perempuan. Di Amerika Serikat, NPB secara umum merupakan penyebab kelima tersering pasien dating berobat. Data lain melaporkan bahwa 7,6\% populasi dewasa di Amerika Serikat mengalami NPB berat selama 1 tahun terakhir, dan hanya 39\% di antara mereka mencari pengobatan (Aninditha \& Wiratman, 2017).

Pasien yang datang dengan NPB harus dieksplorasi etiologic/penyebabnya karena sebenarnya NPB adalah suatu gejala, bukan penyakit. NPB memiliki beberapa penyebab yang mendasari yang harus ditentukan untuk tatalaksana dan prognosisnya. Berdasarkan etiologinya, NPB dibagi menjadi spesifik dan nonspesifik/idiopatik. NPB yang diketahui etiologinya dengan jelas disebut NPB spesifik. NPB yang tidak diketahui etiologinya dengan jelas disebut juga NPB nonspesifik atau idiopatik.

Gejala yang mungkin muncul berupa nyeri punggung bawah yang menjalar ke anggota gerak bawah dengan distribusi dermatomal. Gejala tersebut sering disertai keluhan tebal-tebal sepanjang tungkai dengan distribusi dermatomal, kelemahan dan hilangnya refleks fisiologis pada anggota gerak bawah dengan adistribusi myotomal (Purwata et al., 2019).

Kegiatan pengabdian kepada masyarakat ini bertujuan untuk mengedukasi masyarakat awam mengenai nyeri punggung bawah dan bagaimana pencegahannya. Harapan dari pengabdian ini agar angka kejadian nyeri punggung bawah dan angka kecacatan yang ditimbulkan dapat dikurangi sebanyak mungkin terutama pada daerah NTB. 


\section{METODE KEGIATAN}

Kegiatan pengabdian masyarakat ini dilakukan di poli saraf Rumah Sakit Universitas Mataram pada tanggal 27-28 Mei 2021. Sebanyak 13 pasien saraf yang berada di depan poli mengikuti kegiatan, yang meliputi pre-test, penyuluhan dalam bentuk slide mengenai nyeri punggung bawah (NPB), dan diakhiri dengan post-test. Pre-test dilakukan untuk mengevaluasi tingkat pengetahuan awal pasien tentang nyeri punggung bawah (NPB) sebelum memperoleh materi penyuluhan nyeri punggung bawah (NPB). Soal-soal pre-test yang diberikan adalah 10 butir soal jenis pilihan ganda seputar penyakit nyeri punggung bawah (NPB), dimana setiap pasien diminta untuk menjawab setiap pertanyaan dengan cara memilih salah satu dari 2 pilihan jawaban (format YA/TIDAK). Setiap Jawaban yang benar mempunyai nilai 10, sehingga total nilai maksimal untuk pre-test ini adalah 100.

Pada penyuluhan nyeri punggung bawah (NPB), pasien diberikan edukasi mengenai nyeri punggung bawah (NPB) menggunakan media slide powerpoint yang berupa tulisan dan gambar. Didalam media edukasi tercantum tentang beberapa informasi penting, antara lain pengertian NPB, penyebab NPB, faktor resiko/penyebab, faktor yang memperberat dan memperingan gejala, tanda bahaya nyeri NPB serta tatalaksana sederhana dari NPB. Tahap post-test dilaksanakan dengan tujuan untuk mengevaluasi adanya perubahan tingkat pengetahuan pasien tentang nyeri punggung bawah (NPB). Soal yang diberikan saat post-test dan cara penilaiannya sama dengan soal yang diberikan pada saat pre-test. Dengan demikian, peningkatan pengetahuan pasien dievaluasi berdasarkan perbedaan rerata nilai post-test terhadap pre-test.

\section{HASIL DAN PEMBAHASAN}

Sebanyak 13 pasien telah mengikuti kegiatan pengabdian tentang nyeri punggung bawah (NPB), sebagai upaya pencegahan kelainan atau gangguan pada punggung bawah (NPB). Kegiatan ini meliputi pre-test, penyuluhan mengenai nyeri punggung bawah (NPB) menggunakan media slide powerpoint, dan post-test. Dalam kegiatan pretest dan post-test, para pasien tampak cukup antusias dalam mengerjakan 10 butir soal pilihan ganda yang telah disiapkan sebelumnya (Gambar 1).

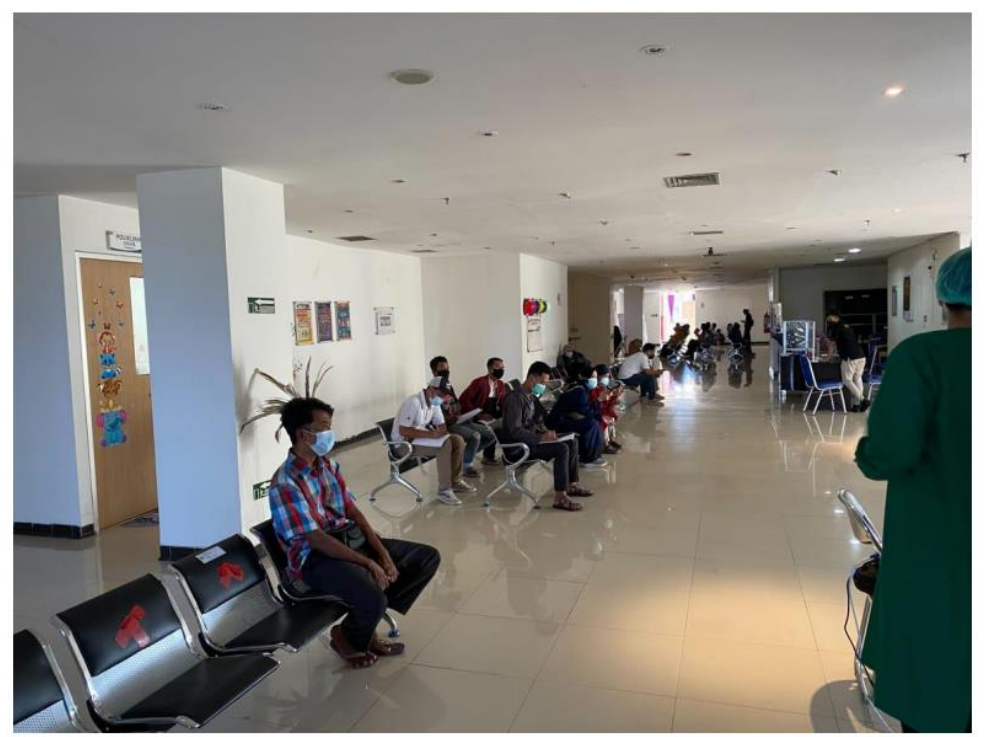

Gambar 1. Pasien saat mengerjakan soal-soal pre-test dan post-test 
Penyuluhan mengenai nyeri punggung bawah (NPB) ini dilakukan dengan menggunakan media slide powerpoint yang mencantumkan informasi, diantaranya adalah pengertian NPB, penyebab NPB, faktor resiko, faktor yang memperberat dan memperingan gejala dan tanda bahaya nyeri NPB. Pasien juga mendapat pengetahuan baru mengenai tatalaksana sederhana dari NPB. Dalam kegiatan ini, pasien di tempat dilakukannya kegiatan pengabdian ini menunjukkan minat yang cukup tinggi. Hal ini disebabkan karena sebelumnya pasien tersebut belum pernah mendapatkan informasi mengenai NPB. Hal ini bisa dilihat dengan antusiasme pasien dalam menerima penyuluhan yang diberikan (Gambar 2).

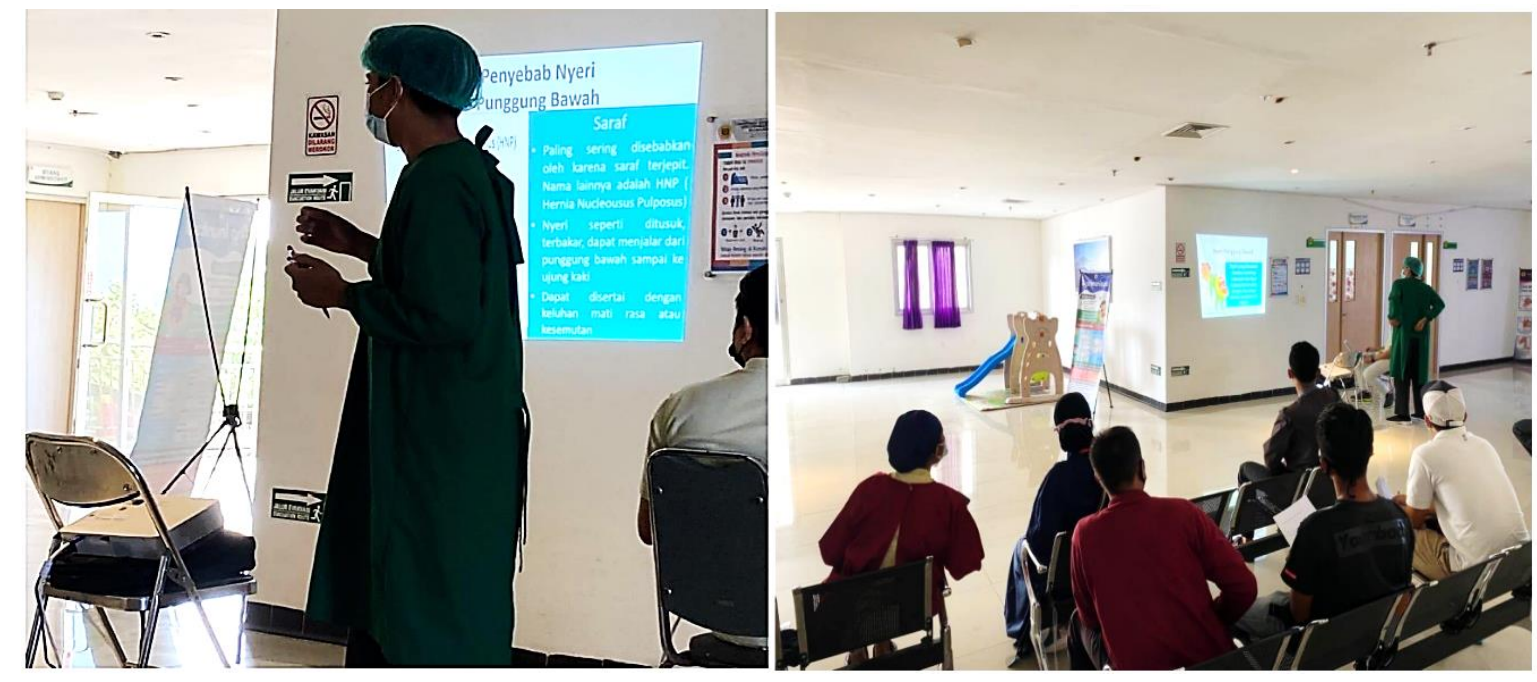

Gambar 2. Pasien saat mengikuti kegiatan penyuluhan NPB.

Rerata nilai post-test yang diperoleh dalam kegiatan pengabdian ini lebih tinggi saat dibandingkan dengan rerata nilai pre-test sebelumnya. Secara rinci dapat dipaparkan perbedaan rerata nilai pre-test dan post-test pada pasien, antara lain rerata 76.9 untuk pre-test dan 82.2 untuk post-test. Sebanyak 9 pasien (60\%) mengalami peningkatan pengetahuan, dan 3 pasien (23\%) tidak menunjukkan adanya peningkatan pengetahuan, namun demikian, ada satu pasien yang pre-test dan post-test nya mendapat nilai sempurna (100), dan dijumpai nilai post-test yang lebih rendah dari nilai pre-test sebanyak 1 pasien (7\%) (Tabel 1 ).

Tabel 1. Data nilai pre-test dan post-test pasien peserta kegiatan pengabdian

\begin{tabular}{lll}
\hline No. & Pre-test & Post-test \\
\hline 1 & 70 & 100 \\
2 & 60 & 80 \\
3 & 80 & 70 \\
4 & 90 & 100 \\
5 & 80 & 90 \\
6 & 100 & 100 \\
7 & 90 & 100 \\
8 & 50 & 70 \\
9 & 80 & 80 \\
10 & 80 & 90 \\
\hline
\end{tabular}




\begin{tabular}{lll}
\hline 11 & 80 & 90 \\
12 & 70 & 70 \\
13 & 70 & 80 \\
Rerata & 76.9 & 86.2 \\
\hline
\end{tabular}

Hasil tersebut menunjukkan bahwa kegiatan pengabdian yang dilakukan di poli saraf Rumah Sakit Universitas Mataram tersebut mampu meningkatkan pengetahuan para pasien mengenai nyeri punggung bawah (NPB) secara signifikan. Pasien dapat menganggap penting untuk bisa mengetahui penyakit ini mengingat mereka telah memasuki usia yang rentan untuk terkena NPB dan kondisi medis tersebut dapat dicegah atau dikurangi perentase kejadiannya. Informasi mengenai nyeri punggung bawah mampu diserap oleh pasien dimana informasi mengenai apa yang dimaksud nyeri punggung bawah (NPB) atau pengertian NPB, penyebab NPB, faktor resiko, faktor yang memperberat dan memperingan gejala serta tanda bahaya dan bagaimana pencegahannya dapat dipahami oleh pasien sehingga informasi ini diharapkan dapat diteruskan ke orang sekitar baik di lingkungan rumah atau lingkungan. Sebagai tambahan pasien juga diberikan pengetahuan sederhana mengenai tatalaksana yang dapat dilakukan saat mengalami NPB.

\section{KESIMPULAN DAN SARAN}

Berdasarkan hasil penilaian pre-test dan post-test dari pengabdian masyarakat ini dapat disimpulkan bahwa mengedukasi masyarakat awam di poli saraf Rumah Sakit Universitas Mataram mengenai nyeri punggung bawah dapat meningkatkan pemhaman pasien tentang nyeri punggung bawah dan bagaimana pencegahannya. Dalam kegiatan pengabdian ini menunjukkan bahwa komunikasi, informasi, dan edukasi (KIE) merupakan solusi yang efektif untuk meningkatan pengetahuan pasien. Hal ini tentunya perlu disertai langkah implementasi, dimana pasien akan melakukan hal-hal yang dapat mengurangi angka kejadian NPB. Jika pasien terdiagnosis lebih awal maka penatalaksanaan berikutnya lebih dapat dilakukan baik secara farmakologi dan non farmakologi.

Pengabdian ini merupakan langkah awal untuk kegiatan intervensi promosi yang perlu ditindaklanjuti dengan kegiatan serupa pada populasi yang lebih luas, sehingga upaya penemuan penyakit NPB menjadi meningkat dan luaran klinis penderitanya menjadi lebih baik. Kegiatan promosi kesehatan tersebut juga perlu diperluas cakupannya pada pasien yang telah mempunyai NPB maupun yang mempunyai faktor risiko NPB. Bagaimanapun pencegahan tetap lebih baik daripada mengobati. Harapan terakhir tentunya menurunkan angka prevalensi kejadian NPB di terutama di daerah NTB.

\section{UCAPAN TERIMAKASIH}

Penulis mengucapkan terimakasih kepada Rumah Sakit Universitas Mataram yang telah memfasilitasi pelaksanaan kegiatan pengabdian ini.

\section{DAFTAR PUSTAKA}

Aninditha, T., \& Wiratman, W. (2017). Neurologi. Penerbit Kedokteran Indonesia: Tangerang. Purwata, T. E., Sadeli, H. A., Yudiyanta, Emril, D. R., Santoso, W. M., \& Tama, W. N. (2019). Konsensus Nasional Penatalaksanaan Nyeri. Perhimpunan Dokter Penyakit Saraf Indonesia : Yogyakarta. 